\title{
Strength Analysis of Policy Based on the Survey Declaring Islamic Law Number. 5 of 2010 West Aceh Regency
}

\author{
Nellis Mardhiah \\ Teuku Umar University / Faculty of Social and Political Sciences \\ Departement of Public Administration \\ $+6281361335392$ \\ nellismardhiah@gmail.com
}

\begin{abstract}
The policy of PERBUP Number 5 of 2010 declaring a manifestation of the policy process that focuses on the application of Islamic fashion in enforcing Islamic law in Aceh Barat District. This study the research her had used is a qualitative approach with the Incremental theoretical analysis that the success of the policy is very large in relation to the policy formulation process for creating the success in its implementation. The results obtained are: the implementation of the rules of PERBUP reflects peoples participation in the development of social policy, one of them wears Islamic dress codes according to the rules of Islam, considering the policy of Islamic law as one of the special autonomy in the province, can prevent immoral acts that against the rules of the code of ethics of Islamic among the people of Aceh in general and particularly among people in West Aceh. The conclusion of this study is the policy of Islamic law in west Aceh district that has been prescribed in the regulations as Regent can show the strength values that will be established in west Aceh district in enforcing Islamic law in the area of Sufism faith (Tauhid Tasawuf).
\end{abstract}

Keywords: Strength, Islamic Law, Public Policy

\section{INTRODUCTION}

Regent Regulation No. 5 of 2010 on the Enforcement of Islamic Sharia Dress Code in West Aceh District is abbreviated as PERBUP.This policy is one of the efforts of local authorities to provide the power of Islamic law that must be adhered by the people. It is based on the position of the government of Aceh as an Indonesian province in the identity of "the unity of the legal community that is both special and specifically authorized to regulate and manage the administrative affairs and interests of local people" (Law Number 11 Year 2006 onGovernance of Aceh, Article 1: 4. Gazette of the Republic of Indonesia Year 2006 Number 62, Supplement to State Gazette of the Republic of Indonesia Number 4633). The law in question is as a rule to wear Islamic fashion for Muslim communities in West Aceh, including the nonMuslim (from outside or foreigners) who enter the territory. The implementation of the PERBUP is generally divided into 11 sections as follows:

i. Provisions general; Article 1 asserts Islamic law as the responsibility of the government of West Aceh district. Implementation of Islamic law is in force in all aspects of life for Muslims and Muslimah(women) who have reached puberty;

ii. Principle and objectives; Articles 2 and 3 confirmed that the basis of the implementation of Islamic law has been governed in the Al-Quran and Hadits;

iii. Norms and ethics of dress; Article 4 stated that Muslim and Muslimah should fulfil the norms and ethics of dress without compromising the aesthetic values of dresses that suit the conditions, time and place;

iv. Scope of application of Islamic dress: Article 5 states that the wearing of Islamic dress imposed on Muslim communities in the West Aceh District and the Muslim entering West Aceh District;

v. Target; this section consists of Article 6, Article 7, Article 8 and Article 9. Article 6 pay attention to the types of Islamic dress that can be worn by men and women. Article 7: emphasis on the types of clothing to groups consisting of a group of professionals, workers, students and sportsmen. Article 8, focuses on fashion 
model for arts and cultural groups. Article 9, gives examples of mode and form of suggested Islamic fashion according to the provisions;

vi. Fashion prohibited; Article 10 gives examples of forms of prohibited clothing;

vii.Development and monitoring; This section contains articles 11,12, 13 and 14. Article 11,12 , and 13 arrange the implementation of tasks by the WH (Wilayatul Hisbah-sharia police) and the Department of Islamic Sharia. Article 14 focuses on the implementation of monitoring;

viii. Saman (sanction); Article 15 is about the penalty for those who disobeying the rule;

ix. Financing; Article 16 is about financing implementation of the PERBUB which is under the responsibility of local budget (APBK);

x. Other provisions; Article 17 is about the implementation of the compliance guidelines for the non-Muslim community of West Aceh and the outside non-Muslims communities;

xi. The closing provision covers the methods of decision making over something that has not been regulated in this.

The Islamic sharia policy law is the result of policy-making process in Aceh province of the Indonesia territorial integrity can be seen from the study (Siregar, 2008) that explained that there were many challenges during the policymaking process in the context of values and Islamic civilization and socio-cultural Indonesia and ideology of Pancasila and the Constitution of the Year 1945 (UUD 1945) in the territory of Indonesia's Islamic nature.Islamic law on power that belongs to the provincial/district level in enforcing Islamic law.

So even in Syafingi study (2012) showed that the Indonesian constitution of 1945 also recognizes the autonomy from the central government to the regional governments in increasing Islamic law. Study results show that the position of the autonomous regions to provide more space at the district level to plan, create a rule or perform a variety of administration within the framework of national requirements (Syafingi, 2012). In addition, the perspective of the implementation of Islamic law as the study Latif (2013); Muhibbuthtabary (2012) and Isa (2012) also explained that Islamic law is the result of a political compromise and negotiation to resolve the conflict between the central government and Aceh government that was established in the era of autonomy in Aceh. In this context, they explain that policy formulation is initiated from the legal basis of the central government of Indonesia to Aceh province on the provided laws as legal basis, namely the Law Number 44 of 1999, Law No. 18 of 2001 and Law No. 11of 2006 , it also recognizes the autonomy of the enforcement aspects of Islamic law. The results of their study found that based on these threelaws a number of legislation has been enacted in order to accelerating the implementation of Islamic law in Aceh province.

Study by Latif (2009), stated that the implementation Islamic sharia in Aceh as political and Islamic sharia law transformation intolaw in both legislation, with Qanun or PERBUP, is a political product that has been produced. The results of the study show that the implementation process is faced with challenges and not easily accepted by society. Sahid (2012) studied Islamic law in Aceh policies that take into account the views of scholars and translated by the existence of Regional Regulation (PERDA) in various areas of Islamic law in Aceh. The results of his study describes the general policymaking Islamic law in Aceh is based on the theory of the relationship between religion and state, the symbiotic paradigm. The argument is that religion requires state and vice versa state also needs religion. Sahid (2012) also argues that the application of Islamic law in Aceh highlighted more symbolic than real. Although there are legal provisions concerning the application of the Islamic law, but the value of Islamic law in practice is very weak. This causes the main goal of applying Islamic law cannot be implemented in full.

Study by Aziz (2012) emphasizes the demands for application of Islamic law can be influenced by domestic politics, including elements of liberalization. According to him, this is the political foundation at this point in 
Indonesian government circles. Results of the research showed that Islamic law as a political element in the position of the unitary Republic of Indonesia as a result of conflict in Aceh peace talks. Study by Fahmi (2012) also reveals about decision-making in the legislation and stated that implementation scenarios PERDA and PERBUP. The study results showed that both the product of legislation is difficult to be accepted by society because of their political interest of decision makers in both institutions.

And therefore, all the results obtained in the study showed significant policy-making that has been made which indicate values of strength in policy implementation. These values can be described in a policy in theory approach presented using incremental theory popularized by Charles E. Lindblom in the 1960s. According to this theory applies for some justification. First, it can explain the incremental element in policy making through the power inherent in the policy-making process. Therefore, this study can give a new perspective, where there is a difference that is made before the general theory that can explain the process of policy making Islamic law made by the government in the application of Islamic dress code in Aceh Barat. But specifically in this study, we want to understand the true values of strength in Islamic law derived from the Al-Quran and Hadits.

\section{RESEARCH METHODOLOGY}

The methods of this study was conducted using qualitative approach by emphasizing the triangulation of data is a way to find out where researchers gather and interpret information from a single source can be verified by reference to the same thing from other sources. In addition, the sources of information that can be obtained correlate that explains the process, the phenomenon by using methods of in-depth interviews that are not structured, open and made face to face with the whistleblower (Lichtman, 2013: 7).

A qualitative approach to mean "different things to different people" (Tesch, 1990: 3). It was used to describe a variety of scenarios such as education, ethnography, psychology, sociology (Tesch, 1990: 3) and the police (Brayman \& Burgess, 1999: 184). For example, it may be beneficial to researchers to explore aspects of the policy implications of the actions of the authorities.

In accordance with a qualitative approach as the description above, the discussion focused on the study design, data collection methods, and data analysis methods. Such appropriate study design used in this study. This is because research centered on generating exploration data on all aspects of the phenomenon are still unclear (Teddlie \& Tashakkori, 2009). While data-driven research relies on unstructured data (Hammersley, 2013). For example the data owned by the government, such as those used in this study is not open to the public unless there is a need of knowledge by researchers for use in carrying out a study.

The location of this research is in the area of West Aceh District. This region is the administrative center of the city and it is also the place where the start of the implementation of the resolution declaring Islamic law in Aceh Barat. Figure 1 below shows the position of each of Indonesia's Aceh province. And the special position of West Aceh District, Aceh Barat district in which the show is based (arrow) is the location of the study. 
Figure 1: Map of Aceh, Indonesia

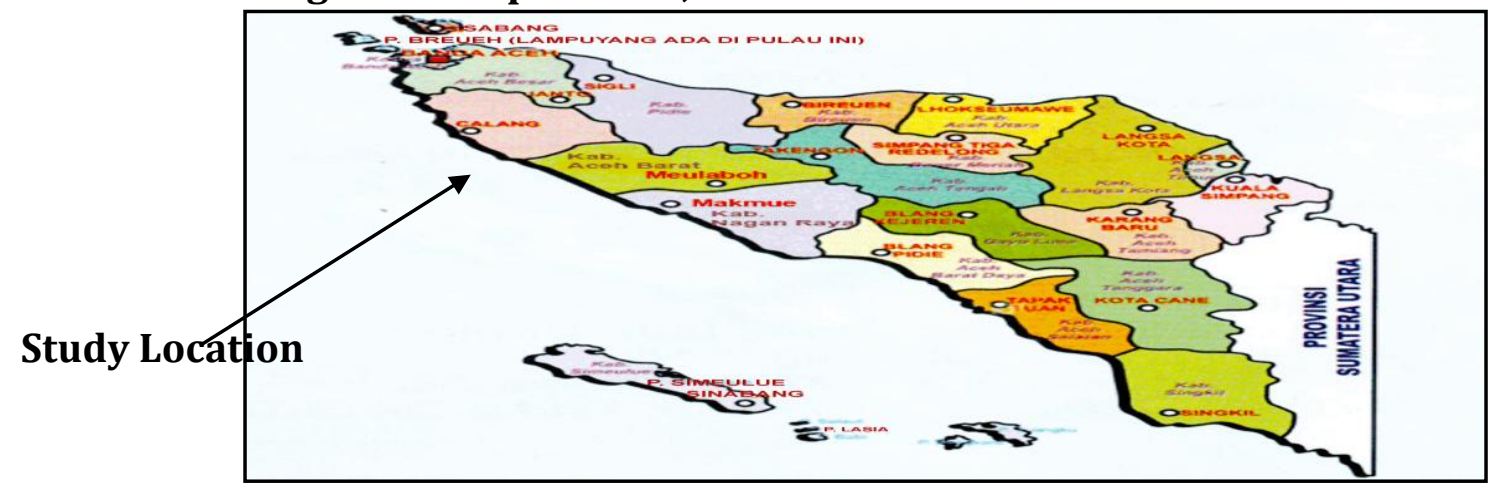

Source: Official Documents Law and Legal Affairs Office of the Head Office of Aceh Barat District, 2013.

The data for this study documents obtained from the Secretariat of the Regent of West Aceh District, especially in the Head Office. In Aceh Barat, the secretariat is divided into several sections, namely, Bupati, Department of Islamic law, Majelis Ulama Aceh, Wilayatul Hisbah, the University Academic Staff, Hizbut Tahrir Indonesia, and FemaleFigure.

Primary data is also dependent on indepth interviews with key informants. In depth interviews means the interview are not structured, not uniform, open and made face to face with the whistleblower (Gwee, 2013). Interviews with questions guide (interview question guide) in the form of semi-structured (semi-structured). It provides an opportunity for open answers given by the informant to the questions that have been formed by the partial structure by researchers. The questions for the interview were built based on the themes that have to do with the research questions and guided by the relevant documents of the study. For this study, informants selected were 13 people.This amount is based on the records of participants involved in the policy making of the document "Decision of the Regent of West Aceh Number 7 of 2010 on the Establishment of the Drafter team for the PERBUP on the Enforcement of Islamic Sharia Dress Code in West Aceh District." However, this study managed to get seven (7) the information only for the remaining officers could not be found (to move to other provinces in Indonesia and had died).

\section{RESULTS AND DISCUSSION}

PERBUP Number 5 of 2010 on the Enforcement of Islamic Sharia Dress Code in West Aceh Districtas the result of the district government policy has been very clearly shows the various laws that are used to support their realization. It begins with consideration to the 1945 Constitution and several laws for Aceh and alerts others to the essential sources of the Qur'an and Hadith.

Existing studies such as policy-making perspective as discussed previously recognized the weakness of trade-related policies produce legal Islamic law in Aceh as well as research support by Cockrel (1997); Muhibbuthtabary (2012); Syafingi (2012) and Isa (2012) is consistent with the case in the implementation of the PERBUP in West Aceh district. In addition, the Incremental theory is the approach in explaining the research objectives are achieved.

The findings of strength in the PERBUP Number 5 of 2010 on the Enforcement of Islamic Sharia Dress Code in West Aceh District. The strength seen in the policy making of the existing studies focused on technical advice, information and fill in the policy-making, policy decisions in assessing the strength of exposing steps in addressing the problem of the policy, involvement of the community as policy appraiser. In terms of technical flaws in the 
policy-making can be shown that the existing studies, as is the case in Nigeria have not found a clear format in resolving policy issues to be addressed (Aguba, 2012). The study results have nothing in common than it is specialized in the analysis of the strengths and weaknesses in policy-making with the PERBUP Number 5 of 2010 in Aceh Barat.
As argued by Charles Lindblom (1959) in the framework of the Incremental theory has been discussed previously (see section on pages concerned) there is an element of power in making decisions based on existing laws. In connection, the results of this study discuss the value of strength in policy-making of PERBUP also shows the value of the power in making decisions. It can be listed in Figure 2 as follows:

Figure 2: The Values of Strength of the Islamic Sharia in Aceh Barat

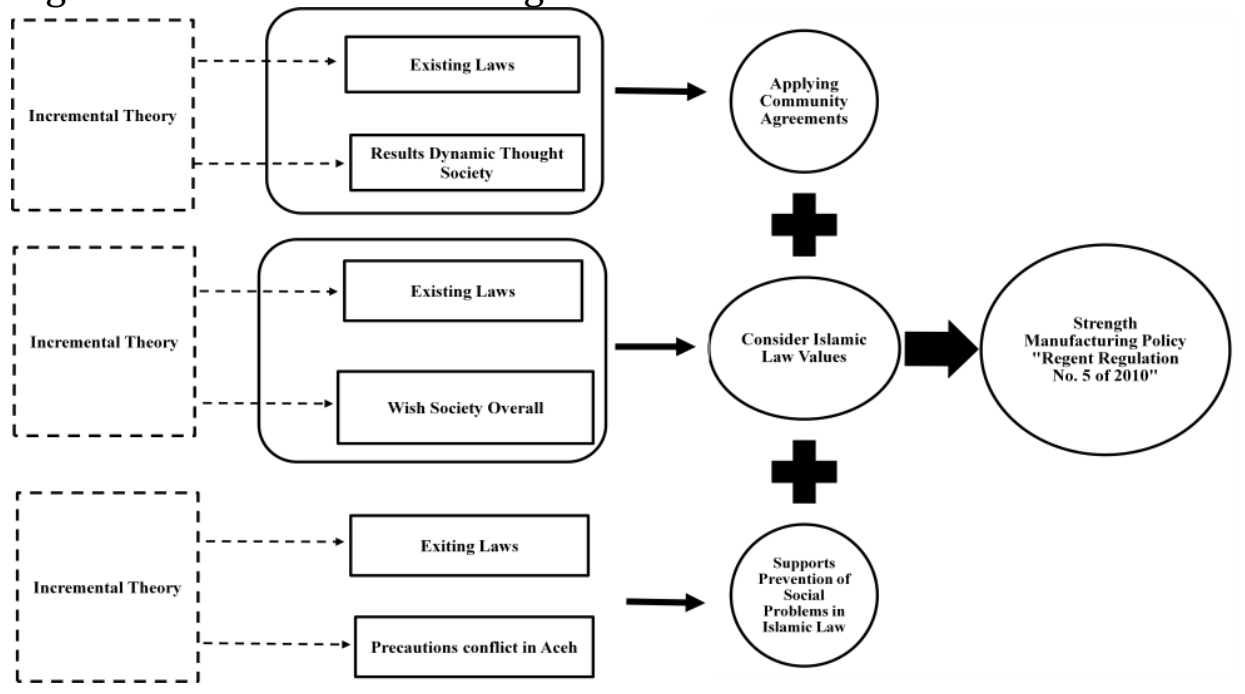

Source: Results of research in 2015/2016.

The findings of the research strengths in implementing the policy of Islamic law in the application of Islamic the fashion in West Aceh district is as follows:

Applying Community Agreements

Applying a community agreement intended to realize the value of compromise in the process of policy-making by the foundation. In the context of this thesis, evidence shows that implementing a community agreement can be mirrored legislation than it is, namely, through Regent Decree Number 1111 of 2009 on the Establishment Committee of the National
Seminar on Enforcement of Islamic Sharia in the use of Islamic Clothing on the Land of Teuku Umar, West Aceh District in 2009, as these guidelines apply community agreement. The basis of this legislation as a guide line as in statements Table 2 about the actions taken by the participants of policy-making that is, through the dynamics of thought is developed based on focus group discussions with communities and the formulation of the respective groups recited in the discussion that took place on Sunday, 20 December 2009. 
Table 1. Implementing Legislation Community Agreements

\begin{tabular}{|c|c|}
\hline Laws & Explanation \\
\hline $\begin{array}{l}\text { Decree Number } 1111 \text { of } 2009 \text { on the } \\
\text { Establishment Committee of the National } \\
\text { Seminar on Enforcement of Islamic Sharia } \\
\text { in the use of Islamic Clothing on the Land of } \\
\text { Teuku Umar, West Aceh District }\end{array}$ & $\begin{array}{l}\text { i) The dynamics of thought that developed } \\
\text { based on discussions with community } \\
\text { groups; } \\
\text { ii) Summary of each group read out at a } \\
\text { plenary discussion which took place on } \\
\text { Sunday, December 20,2009. }\end{array}$ \\
\hline
\end{tabular}

Source: Data Documents and field studies, 2015/2016

In addition to the involvement of various parties, the support of the government and scholars also encourage compromise to achieve the goals of the policy making of the Perbup. Government support can be seen from WH functions as the statement that "The implementation and enforcement of fashion was assigned to $\mathrm{WH}$ is a function of the development and supervision of the implementation of Islamic law. Development and supervision of the application of Islamic law is implemented by Wilayatul Hisbah (WH), in coordination with the Department of Islamic Sharia and traditional institutions and other religious positions in the district of Aceh Barat "(Source: the decree Number. 5 of 2010 on the Enforcement of Islamic Law In Application of Islamic Clothing in West Aceh District: 10).

While the support of the clergy can be seen through the statement is "a religious life of Acehnese society, uphold the tradition, and scholars have been put on a respectable role in the social, civic, and formed to be preserved and developed in conjunction with the development of education. In connection with such matters, the regional administration that need legal certainty in the conduct of affairs, it is necessary to enact the Act on the Implementation of Aceh Province Privileges "(Source: Document explanation of Law No. 44 of 1999: 4).
The above shows that various considerations taken into account in policymaking of the Perbup. So it is a strength that the implementation of the compromise essential in order to reduce conflicts and maintain stability of the political system itself.

The government guidelines that are used in implementing the agreement is mirrored through the dynamics of the group thought that the debate recognized through the implementation process. In the process of debate, as discussed in Chapter 4, the National Seminar on Islamic fashion and in the Southeast Asia Ulama Conference. National Seminar on Islamic Clothing plays a role in bringing the essence of the debate is about Islamic dress and recommendations in enforcing Islamic law by such methods. The essence of the important debate, which later became resolution of the seminar is relevant forms of fashions in Islam, and Muslim and non-Muslim state in the use of fashions. Apart from the essence of the dimensions of emphasis also involves issues of human life includes haute perspective of jurisprudence, human rights and legislation in Indonesia, dress in perspective of Islamic civilization and culture, women's participation in Islamic fashions diversity, and socialization strategy of Islamic dress and the establishment of formal education. Table describes the above.actions

Table 2. The action of the policy-making participants in applying community agreements

\begin{tabular}{|l|l|}
\hline Results of Dynamic Thinking Group & Explanation \\
\hline $\begin{array}{l}\text { The fashions in islamic Fiqh perspective, } \\
\text { Human Rights and Legislation in Indonesia }\end{array}$ & $\begin{array}{l}\text { Prohibits a Muslim or Moslem wear Islamic } \\
\text { dress is a violation of Human Rights }\end{array}$ \\
\hline $\begin{array}{l}\text { Fashions in the perspective of Islamic } \\
\text { civilization and culture }\end{array}$ & $\begin{array}{l}\text { Contains the values of religious, social and } \\
\text { cultural }\end{array}$
\end{tabular}


Table 2, cont.

\begin{tabular}{|l|l|l|}
\hline $\begin{array}{l}\text { Women's participation in Islamic fashions } \\
\text { diversity }\end{array}$ & $\begin{array}{l}\text { Optimal involvement of women in the } \\
\text { planning and socialization }\end{array}$ \\
\hline $\begin{array}{l}\text { Dissemination strategy and the } \\
\text { establishment of Islamic dress formal } \\
\text { education. }\end{array}$ & $\begin{array}{l}\text { Provide facilities, education, persuasion and } \\
\text { coercion. }\end{array}$ \\
\hline
\end{tabular}

Source: Data Documents and field studies 2015/2016.

\section{i. $\quad$ Considering Values of Islamic Law}

PERBUP manufacturing process is done by considering the values of Islamic law also intends to inject the implementation of Islamic law as a new element to the existing administrative system. Considering the Islamic sharia law from the existing laws.

Under the law in question as shown in Table 4, namely, (i) Implementation of Law Number 44 of 1999; (ii) Implementation of Law Number 11 of 2006 supported by clear consideration in the administration of Islamic law in Aceh. Law Number 44 of 1999 stressed that "Islamic law is the claim of Islam in all aspects of life" (Article 1 of Law No. 44 of 1999: 1). Whereas Law Number 11 Year 2006 stressed that "further implementation of Islamic law can be arranged in the form of Qanun (Article 125 of Law Number 11 Year 2006: 87).

Table 3. Consideration of the existence of Islamic Law

\begin{tabular}{|l|l|}
\hline \multicolumn{1}{|c|}{ Law } & \multicolumn{1}{|c|}{ Pertimbangan Nilai Syariat Islam } \\
\hline Law Number 44 of 1999 & $\begin{array}{l}\text { "Islam is the claim of Islam in all aspects of } \\
\text { life" (Article 1 of Law No. 44 of 1999: 1). }\end{array}$ \\
\hline Law Number 11 of 2006 & $\begin{array}{l}\text { "The implementation of Islamic law can be } \\
\text { arranged more in the form of Qanun (Article } \\
\text { 125 of Law Number 11 Year 2006: 87) }\end{array}$ \\
\hline
\end{tabular}

Source: Data Documents and field studies 2015/2016.

The product of Islamic law on Islamic dress in Aceh Barat is the desire of the community as a whole. Interview said that the implementation of Islamic law in Aceh is already taken into consideration in the life of the people of Aceh in enforcing Islamic law. The status of Aceh as a special region and autonomous region are seen to have the ability to enforce Islamic law in Aceh province. So people in West Aceh as part of Aceh province wants to create a realistic application of Islamic dress in accordance with the principles of Islam, whichare $\mathrm{Al}-\mathrm{Quran}$ and $\mathrm{Al}$ Hadith

\section{SUPPORT PREVENTING SOCIAL ISSUES ACCORDING TO ISLAMIC LAW}

Preventing above mean actions aimed to prevent immoral acts that violate the enforcement of the rules of Islamic law. This may indicate a slight modification to the existing policy, can also be seen in the force behind the creation of the Perbup. Thus, supporting the prevention of social problems according to Islamic law is implicit value judgments in favour of the modification. This is a positive step because it is a business that supports the welfare of society by preventing the occurrence of social problems.
Considering the dimensions of Islamic law there are two measures that can indicate the condition of the existing law. Under the law, Table 5 shows that regulatory supports are (i) Nanggroe Aceh Darussalam Province Qanun No. 12 of 2003; (ii) Nanggroe Aceh Darussalam Province Qanun No. 13 of 2003 and (iii) Nanggroe Aceh Darussalam Province Qanun No. 14 of 2003. Under these laws,it is emphasized how the status of works or social actions that violate Islamic law and its justification prevention. For example, 
"Drinking wine or liquor and the like is a violation of Islamic law". Justification prevention is aimed at "preventing acts or events that arise from a beverage in the community" (Article 3 of Nanggroe Aceh Darussalam Province Qanun No. 12 of 2003: 4). It is available in Nanggroe Aceh Darussalam Province Qanun No. 12 of 2003. In addition, "Maisir or gambling is one wrong act forbidden in Islamic law". Justification prevention is to "prevent members of the public to do the act which led to Maisir or gambling" (Article 3 of Nanggroe Aceh Darussalam Province Qanun No. 13 of 2003: 3). It is available in Nanggroe Aceh Darussalam Province Qanun No. 13 of 2003.

Table : Statement of Existing Laws to Support Preventing Social Issues According to Islamic Law

\begin{tabular}{|l|l|l|}
\hline \multicolumn{1}{|c|}{ Law } & \multicolumn{1}{|c|}{ Explanation } & \multicolumn{1}{c|}{ Justification } \\
\hline $\begin{array}{l}\text { Aceh Darussalam Nomber 12 } \\
\text { of 2003; }\end{array}$ & $\begin{array}{l}\text { Drinking wine or } \\
\text { liquor and the like is a } \\
\text { violation of Islamic } \\
\text { law }\end{array}$ & $\begin{array}{l}\text { "Preventing acts or events that } \\
\text { arise from a beverage in the } \\
\text { community" (Article 3 of } \\
\text { Nanggroe Aceh Darussalam } \\
\text { Province Qanun No. 12 of 2003: } \\
\text { 4). }\end{array}$ \\
\hline $\begin{array}{l}\text { Qanun Provinsi Nanggroe } \\
\text { Aceh Darussalam Number 13 } \\
\text { of 2003; }\end{array}$ & $\begin{array}{l}\text { Maisir or gambling is } \\
\text { one wrong act } \\
\text { forbidden in Islamic } \\
\text { law }\end{array}$ & $\begin{array}{l}\text { Preventing members of the } \\
\text { public to do the act that led to } \\
\text { Maisir or gambling" (Article 3 of } \\
\text { Nanggroe Aceh Darussalam } \\
\text { Province Qanun No. 13 of 2003: } \\
\text { 3). }\end{array}$ \\
\hline $\begin{array}{l}\text { Qanun Provinsi Nanggroe } \\
\text { Aceh Darussalam Number 14 } \\
\text { of 2003; }\end{array}$ & $\begin{array}{l}\text { Seclusion or meusum } \\
\text { is one wrong act } \\
\text { forbidden in Islamic } \\
\text { law }\end{array}$ & $\begin{array}{l}\text { Preventing people from } \\
\text { comight lead to adultery" (Article 3 } 3 \\
\text { of Nanggroe Aceh Darussalam } \\
\text { Province Qanun No. 14 of 2003: } \\
\text { 2). }\end{array}$ \\
\hline
\end{tabular}

Source: Data Documents and field studies 2015/2016.

For the above actions, the results of interviews with informants explained that Perbup as a policy is a very positive action in enforcing Islamic law with the ability by the government to support the prevention of social problems by regulating the use of Islamic law in the Islamic fashion.

\section{CONCLUSIONS}

The power of decision-making on "the decree No. 5 of 2010". These forces consist of the implementation of the agreement that formed the community of law that is based on the dynamics of group thinking in establishing the rule of Islamic law. Considering the values of Islamic law based on the laws that already exist, and the implementation of Islamic law as the desires of the community as a whole. And support the prevention of social problems according to Islamic law as the government's actions in the prevention of conflict in Aceh.
Implementation of the agreement reached by the compromise. This implementation is the result of the dynamics of the thinking of various groups in policy decision-making. Recognition of these two things is based on existing laws. The results dynamic thought the group consisting of: Clothing Fiqh perspective, Human Rights and Legislation in Indonesia; Clothing in the perspective of Islamic civilization and culture; Participation of women in Islamic dress and model diversity outreach strategy and the establishment of Islamic dress formal education commodities. 
Considering the Islamic law is the wishes of the people as a whole based on existing law. Implementation of Islamic law has been considered the life of the people of Aceh in enforcing Islamic law. And people want to create a realistic application of Islamic clothing became a necessity in our daily lives.

Supports the prevention of social problems according to Islamic law is the prevention of conflict in Aceh. This built on the existing legislation in regard to the Islamic Sharia as the prevention of conflict in Aceh, is to support positive action that has occurred prior to the enactment of the UUPA in 2006 as an autonomous province of Aceh in enforcing Islamic law.

\section{SUGGESTIONS}

Policy makers are expected to follow the Perbup Number 5 of 2010 at this time. It shows of doubt in people's lives become controversial for society in the implementation of the Qanon of Islamic law, which is caused by a new breakthrough is Qanun Jinayah No. 4 of 2014, which is also one of the means to enforce Islamic law in Aceh province.

The strength of Islamic law must be in a position again among laws and regulations that apply today. Islamic law must be carried out as a basis for legal provisions for Muslims, especially for people who are in the province of

\section{APPRECIATION STATEMENT}

For the implementation of this study, researchers would like to thank all those who have contributed to the success of this research:

Research is a scientific activity that is almost certainly done in groups or through cooperation. In the world of science and technology has advanced as now, no single model of field research conducted only by the

\section{REFERENCE}

Siregar, H. . (2008). Lesson Learned From the Implementation of Islamic Syariah Criminal Law In Aceh. Juornal of Law and Review, 24(2), 143-176.

Hooker, M. B. (2008). Indonesian Syariah: Defining a National School of Islamic Law (p. 246). Singapore: ISEAS.

Arskal, S. (2004). Sharia from Below in ACEH (1930s-1960s): Islamic Identity and the Right to Self-Determination with Comparative Reference to the Moro Islamic Liberation Front
Aceh has been stipulated in the Law No. 11 of 2006 concerning the Government of Aceh, that allaspects of government policy must be based on Islamic law.

Policy makers are expected to be able to communicate well in the stages of socialization reinforced the institutional agenda at the level of village government. This action continuously can be realized to maximize the development of Islamic law, either Top-Down or Bottom-up, to be with the hopes of preventing conflict in society.

research team. This research was conducted in West Aceh District.

Thanks to the Dikti which has given the operational budget of 2015 as in the process of competitive research grants. Everything is a form of cooperation that explicitly shows that in the world of research we cannot act as a lone warrior.

(MILF). Indonesia and the Malay World, 32(92), 80-99.

Arskal, S. (2008). Challenging the Secular State: The Islamization of Laws in Modern Indonesia (p. 4). Honolulu: Hawaii University Press.

Syafingi, H. M. (2012). Nilai-nilai Hukum Islam dalam Peraturan Daerah Syariat Islam di Indonesia. Reasearch Law Juornal, 7(2), 136-146.

Latief, H. M. A. (2013). Disonansi Qanun Syariat Islam dalam Bingkai Konstitusi Hukum Indonesia: Aceh sebagai Studi Kasus. In Annual 
International Conference on Islaimc Studiea (p. 2279). Surabaya.

Muhibbuthtabary. (2012). Membumi Perdamaian Dalam Bingkai Syariat Isla Di Aceh. Media Syariah, 2(1), 12

Isa, A. G. (2012). Paradigma Syariat Islam Dalam Kerangka Autonomi Khusus (Studi Kajian Di Provinsi Aceh). Media Syariah, XI(1), 253

Ayuba A. Aminu, Tella, C. M., \& Mbaya, P. Y. (2012). Public Formulation and Implementation. Journal Public and Administration Research, 5(2), 57.

Latief, H. M. A. (2009). Sengkarut Syariat AtasBawah: Gelombang Baru, Edisi IV (p. 113). Banda Aceh: Komunitas Tikar Pandan.

Sahid. H.M. (2012). Formulasi Syariat Islam dalam Pandangan Ulama dan Struktural (p. 395). Surabaya: IAIN

Aziz, A. (2012). Syriat Islam: Polemik Panjang Hubungan Islam dan Negara di
Indonesia. Hukum Kajian Islam, IV(2), 203.

Fahmi, C. (2012). Transformasi Falsafah dalam Penerapan Syariat Islam di Aceh. In Jurnal KAjian Hukum Islam (Vol. 6, p. 167). Banda Aceh: IAIN ARRANIRY.

Cockrel, J. (1997). Public Policy Making America Cooperative Axtention Service. IP 19. University of Kentucky College of Agriculture, Lexington, and Kentucky State Universit, University of Kentucky Cooperative Extension Service.

Lindblom, C. (1959). The Science of Muddling Throug, Bargaining. Public Administration Review, 19(2), 7988.

Lichtman, M. (2013). Qualitative Research in Education A. User's Guide (p. 7). United 